\title{
On the legal Protection of infringement of Citizens' right of reputation
}

\author{
Yan-Xia WANG \\ Xi'an Institute of Finance and EconomicsXingzhi College Distinct addresses: 57 Di Zhai Road, \\ Shannxi X'an 710038, China \\ Email: 1195810433@qq.com
}

Keywords: the right of reputation; Personality right ; Human dignity

\begin{abstract}
Reputation, as an intangible asset, has brought many benefits to the social subject. However, with the development of social science and technology, there are more and more acts of infringing on the right of reputation. At the same time, the act of infringing upon the right of reputation of citizens also occurs frequently. And the forms of infringement of reputation rights and the behavior of infringing reputation rights are more and more complex and diverse, which makes people difficult to identify. As a result, the rights of citizens are infringed upon, not only infringes the human dignity of the citizen, but also causes the spiritual trauma which is difficult to heal and indirectly caused by the loss of civil property. Therefore, in view of this phenomenon, this paper mainly discusses the infringement of citizens' right of reputation. The legal characteristics of the tortfeasor and the legal liability that the tortfeasor should bear;Citizens whose rights have been violated can better protect their reputation after they understand the infringer's infringement.
\end{abstract}

\section{First, the concept of the right of reputation.}

The right of reputation is a legal right of citizens or legal persons. It is a personality right stipulated and protected by the civil law of our country. Moreover, this right is also stipulated in the Constitution. Thus, the law of our country guarantees the rights of citizens and legal persons. According to the relevant laws and regulations of our country, the right of reputation mainly refers to the right of our citizens and legal persons to obtain their own reputation in the social life in order to enjoy the right not to be infringed by others according to law. The right of civil reputation includes not only the right of name, but also the right of privacy, the right of honor and the right of portrait. These are maintained. Reputation, including human dignity and reputation, is an important component of civil personality rights, and directly protected by the law. The right of reputation has a special attribute, it is inherent in citizens or legal persons, and it is inseparable from their personal rights, and not deprived by others. Reputation can not be disposed of, not transferable, can not be abandoned, citizens' right to reputation begins at birth.

\section{Second, the characteristics of infringement of citizens' right of reputation.}

According to the provisions of the relevant laws of China's General principles of Civil Law and the interpretation of the Supreme people's Court, the author thinks that the behavior of infringing upon citizens' right of reputation should have the following characteristics:In terms of the way of infringement, when infringing the right of civil honor, takes insults, slanderous ways, and openly damages the reputation of citizens, which has already constituted an act of infringement. Slander refers to the act of fabricating and spreading certain false facts and damaging the reputation of others. Insulting, it mainly refers to the use of language and behavior to openly damage the personality of citizens and to destroy their reputation in society. Slander and insult should be an open act. As for public insults and libel within the scope of the law, there is also a definite scope, restriction, when it comes to insulting two or three citizens and insulting others, such acts are regarded as open aggression. At the same time, other acts of infringement of the right of reputation are committed in writing and orally, insulting, slandering others and damaging the reputation of the period. At the same time, there are also acts of infringement of the right of reputation without the 
presence of a third person. The use of tape recorders to broadcast calls and scold, as well as the insults of the infringers themselves, all belong to acts that infringe upon citizens' rights of reputation, although such insults are acts of abuse. It does not necessarily cause public influence in society, but the lack of this behavior has infringed on the dignity of the citizen and has constituted an infringement on the right of reputation of the citizen. Therefore, the author believes that the act also constitutes an infringement of citizens' right of reputation.From the point of view of the object of infringement, the victim should be a specific subject.Mainly refers to natural persons. In the right of reputation infringement, under certain circumstances, under certain conditions, can be specific to someone, also do not have to name, has already constituted an infringement. For example, for some "documentary" literary works 。In the description of his article, he insults and vilifies a particular character, although he uses the code name and pseudonym of his task to address him, but for the reader, he can know what he is referring to at a glance and then author can be regarded as an infringement.

From the objective point of view, there is an illegal infringement of the right of reputation for others. For the fact of reputation infringement, it is mainly that the tortfeasor can damage the personality right of the other person, and it will also bring about a certain damage to the reputation of the citizen. I think that the false or not the content of the statement should be judged first, but this is not a prerequisite for the infringement of the right of honour. Only an act of the infringer's statement which is prohibited by law and which is harmful to the personality and reputation of another person, that is, the fact that the right of reputation of the citizen is infringed, can be regarded as an infringement of the right of reputation of the citizen. If the statement is true and does not impair the personality, reputation, or the law of another person, it does not constitute an infringement of the right of reputation of a citizen; on the contrary, if the statement is contrary to the provisions of the law and the statement made is harmful to the reputation of the other person, and the facts are involved, It will constitute an infringement of citizens' right of reputation.

From the point of view of the subjective fault of infringing upon the citizen's right to honor, the infringer . Most of them are intentional, and some of them are negligent. In reality, it is only intentional for the aggressor to infringe upon the reputation of others by means of slander and insult. In the legislation of tort liability, its aim is to protect citizens' legitimate rights and interests effectively, and to protect citizens' reputation in an all-round way. Be it intentional or negligent, take the initiative to restore the reputation of the citizen and give corresponding compensation.

Judging from the consequences of reputation infringement, the tortfeasor gives the victim who is more serious damage to his reputation.And the reputation of the citizen is seriously damaged, and the reputation of the citizen is seriously affected and the consequences are heavier. The consequences include causing mental harm to citizens, serious damage to citizens' property and serious damage to citizens' health and life. In fact, because the infringer infringes on the citizen's right of reputation, it will make the aggrieved citizen subject to public opinion, condemn, have a negative effect on the citizen's mental health, and make him feel the mental and psychological double torment; and to the victim's work and life caused inconvenience, property suffered indirect losses. The author believes that as long as the infringement is given to the infringed person of the consequences of man-made losses constitute a violation of citizens' right of reputation.

\section{Third, the responsibility to infringe on the right of reputation.}

The right of reputation is of great significance to the civil subject. Good reputation is the basis for civil subjects to engage in social activities. It is difficult to imagine that a citizen or legal person with bad reputation can carry out normal civil contact with others. The author thinks that for citizens, reputation itself is not a kind of property, which can mainly reflect the civil subject.Spiritual interests. Therefore, they are entitled to compensation, including moral or material damage, when their reputation is damaged. The reason is: first, the damage to the reputation of the citizen must bring him mental pain and pressure, the victim has the right to ask for material compensation. Secondly, if a citizen is engaged in economic activities, only if he has a good social evaluation can 
he win the trust of others, win the cooperation of others, and thus create social wealth.Thirdly, the right of reputation indirectly reflects the property interests of citizens, and directly reflects the spiritual interests of citizens. For example, a citizen who is happy in body and mind will create a lot of benefits in the work unit, otherwise, it will be damaged. If a citizen's reputation is good, it will bring him a lot of intangible assets. Otherwise, he may lose some intangible assets. Therefore, the author thinks that the damage to the citizen's reputation will also indirectly cause the loss of his property.

If the act of the infringer causes damage to the victim's right of reputation.In fact, it is the act of infringing and citizens' reputation, which results in the psychological burden of the aggrieved citizens, and the feeling of social pressure of injustice, as well as the mental torture suffered by them, and the psychological trauma of the citizens. And the property suffered indirect losses, the infringer should compensate him for the damage caused to the victim, the victim can bring a civil action to the people's court in the jurisdiction.Infringement of citizens' right of reputation should be responsible for criminal liability, administrative liability and civil liability according to the consequences of infringement. According to the author's research, the needle has blatantly insulted and fabricated facts to slander others, especially if the circumstances are serious enough to constitute a criminal fact. They may be investigated for the corresponding criminal responsibility of the aggressor; and those who openly slander or insult the reputation of others in public places may be subject to administrative punishment in accordance with the "regulations on Administrative penalties for Public Security" by the public security organs, and at the same time, they can also be used as administrative punishments.In the case of public places where the right of reputation is openly defamed and insulted, the public security organ may carry out administrative penalties in accordance with the regulations on punishment for Public Security Administration, and at the same time, it may also act as an administrative punishment with Civil litigation cases should be handled. When a citizen's reputation infringement occurs, according to the provisions of articles 120 and 134 of the General principles of the Civil Law of the people's Republic of China, the infringer shall bear the corresponding civil liability. There are several ways in which the tortfeasor is liable for infringement:

(1) Stop infringement. That is, the court should order to stop infringement of citizens' right of reputation.For a person to stop its original infringement, For example, if a citizen's reputation is infringed by means of a letter, he should be ordered to stop the act so as not to cause more harm to the citizen.

(2) Restore one's reputation. The infringer should restore the reputation of the infringed citizen within the scope of infringement, so that the injured citizen can reduce the mental trauma and reduce the indirect property damage that may result from the infringement.

(3) Eliminate the influence and apologize. The tortfeasor should make a public declaration to the infringed citizen within the scope of infringement, and take certain factual actions to eliminate the act or omission which is harmful to the reputation of the citizen. It is the citizen who reduces the pain in his heart and $r$ the pressure of the citizen's spiritual. To eliminate the influence on the reputation of citizens, and to make amends by way of apology, written or oral apology, to make up for the influence caused by the infringement of reputation to the citizen; when used, the contents of the apology must also be examined by the people's court in advance.

\section{Reference:}

[1] Wang Liming. A New discussion on Personality right Law [M] .Jilin: Jilin people's Publishing House (in Chinese).

[2] Zhang Junjie. Principles of civil law [M]. Beijing: China University of Political Science and Law press, 1997.

[3] Zhang Xinbao.legal protection of reputation [M] .Beijing: China University of political Science and Law Press 1997. 